\title{
ENKELE OPMERKINGEN OVER PRODUCTIE-PROGRAMMERING 1)
}

\author{
door J. B. Polak
}

\section{Inleiding}

In het nummer van januari 1957 van dit tijdschrift schreef de Heer J. Winselaar een beschouwing over: „Het belang van de splitsing in constante en variabele kosten voor de productie-programmering", naar aanleiding van een artikel van W. E. Harrison in ,The Accountant". Harrison stelde, dat indien een bedrijf verschillende artikelen produceert en eenmaal over een bepaalde productie-apparatuur de beschikking heeft, de brutowinst (gedefinieerd als verkoopopbrengst minus variabele kosten) die op ieder artikel gemaakt wordt, de maatstaf ter bepaling van het productieprogramma moet zijn.

Bij zijn critische beoordeling van Harrison's theorie ging Winselaar uit van de productie van een artikel $P$ en van een artikel $Q$, waarbij hij de volgende bijzonderheden gaf:

1. De jaarlijkse capaciteit van het bedrijf bij volledige bezetting is 100.000 werkeenheden 2 ), waarvan de constante kosten $f 100.000,-$ bedragen, dus $f 1,-$ per werkeenheid.

2. De kostprijzen van de artikelen waren als volgt samengesteld:

constante kosten

variabele kosten directe materialen directe lonen

\begin{tabular}{cc|cc}
\multicolumn{1}{c|}{$\mathrm{P}$} & \multicolumn{2}{c}{$\mathrm{Q}$} \\
\hline$f$ & $8,-$ & $f$ & $2,-$ \\
& $1,-$ & & $7,-$ \\
& $1,-$ & $"$. & $1,-$ \\
\hline $\mathrm{f}$ & $10,-$ & $\mathrm{f}$ & $10,-$ \\
\hline \hline
\end{tabular}

3. De verkoopprijzen van $P$ en $Q$ zijn onafhankelijk van de afgezette hoeveelheden en bedragen resp. voor $P$ f $9,-$ en voor $Q f 11,-$

In het eerste door Winselaar onderzochte geval (a) kon de volledige productie tegen de hierboven genoemde verkoopprijzen worden afgezet. Uit Winselaar's cijfervoorbeelden kan men zien, dat hij van mening is, $1^{\circ}$ dat de totale netto-winst en de totale bruto-winst tot een gelijke - en tevens juiste - uitspraak omtrent het productie-programma leiden. $2^{\circ}$ Dat de bruto-winst per artikel tot een onjuiste uitspraak voor het productieprogramma leidt.

In het tweede door hem onderzochte geval (b), waarin de afzet en de productie beperkt zijn ondersteld, concludeert Winselaar, dat de brutowinst per artikel wél richtlijn voor de productie dient te zijn.

Winselaar zal het ons niet euvel duiden, wanneer wij zijn eigen woorden met een kleine variatie opnieuw gebruiken en constateren, dat "na lezing van zijn artikel blijkt, dat de door hem verkondigde theorie op bepaalde punten in belangrijke mate afwijkt van de hier te lande geldende opvattingen. Teneinde tot een verantwoorde conclusie te kunnen komen met betrek-

1) Gaarne breng ik dank aan de Heer A. Heertje, econ. drs., voor zijn hulp bij de opbouw van dit artikel.

2) Wij geven t.a.v. duurzame productiemiddelen de voorkeur aan het gebruik van de term "werkeenheden" boven ,eenheden". 
king tot Winselaar's theorie, zal onderzocht dienen te worden of, en zo ja in hoeverre, zijn theorie voor toepassing vatbaar is".

Waar Winselaar een oplossing gaf voor gevallen die berusten op bepaalde door hem gekozen waarden voor de diverse grootheden, willen wij trachten de oplossing wat algemener te stellen.

\section{Geen afzetbeperkingen}

Wij zullen eerst het geval nagaan, waarin de volledige productie tegen de gegeven verkoopprijzen kan worden afgezet.

Wij nemen aan, dat voor ieder der artikelen de verkoopprijs de variabele kosten overtreft, want was dit niet zo, dan zou van het betreffende artikel niets geproduceerd moeten worden.

Onder de gemaakte veronderstellingen zijn maar twee combinaties van hoeveelheden $\mathrm{P}$ en $\mathrm{Q}$ mogelijk, waarbij de maximale winst bereikt kan worden, nl. óf als er o eenheden $\mathrm{P}$ en het maximale aantal eenheden $\mathrm{Q}$ geproduceerd worden, of bij productie van het maximale aantal eenheden $\mathrm{P}$ en van o eenheden $\mathrm{Q}$. Want wanneer - gegeven de bruto-winst op ieder der artikelen - de vervanging van één artikel $\mathrm{P}$ door een overeenkomstig aantal artikelen $Q$ (dit aantal hangt af van de mate, waarin voor 1 eenheid van de beide artikelen beslag wordt gelegd op de beschikbare productiecapaciteit) tot een toevoeging aan de totale bruto-winst leidt, zal men zo lang met substitueren door moeten gaan, tot het laatste artikel $\mathrm{P}$ door het corresponderende aantal eenheden $\mathrm{Q}$ is vervangen.

Welke combinatie in een concreet geval in aanmerking komt, hangt niet uitsluitend af van het feit, of er voor het ene product meer of minder werkeenheden van het duurzame productie-apparaat benodigd zijn dan voor het andere.

Winselaar verwijt Harrison, dat hij - wanneer hij de bruto-winst per artikel als maatstaf kiest - geen rekening houdt met de hoeveelheden werkeenheden van het duurzame productie-apparaat, die voor de productie van één artikel $P$ resp. één artikel $Q$ benodigd zijn.

De keuze van één van de beide mogelijke combinaties van hoeveelheden $P$ en $Q$ hangt echter mede af van de grootte van de verkoopprijzen en de variabele kosten.

Het blijkt, dat Winselaar in het geval van beperkte afzet en onderbezetting (hierna te behandelen) wél de bruto-winst per artikel als maatstaf aanvaardt en daarom is het wellicht niet overbodig om reeds hier vast te stellen, dat de bruto-winst per artikel nooit een juiste maatstaf voor de productie kan zijn.

Een bedrijf is nu eenmaal niet opgericht om per artikel een zo gunstig mogelijk resultaat te bereiken. Het bedrijf streeft, zoals Limperg nog in zijn afscheidsrede zei, naar eer zo hoog mogelijk duurzaam rendement, hetgeen aan de bruto-winst per artikel niet af te lezen is.

Het behoeft ons dan ook niet te verbazen als straks blijkt, dat wij ook in het geval van beperkte afzet en onderbezetting tot een verkeerde uitspraak komen, wanneer wij ons door de bruto-winst per artikel laten leiden.

Ter illustratie kan hetgeen hierboven betoogd is nog eens in enige formules uitgedrukt worden. ${ }^{3}$ )

3) Aangezien alle relaties die hier een rol spelen van lineaire aard zijn, is het onder. havige een vraagstuk van lineaire programmering.

m a b blz. 162 
Wij voeren daartoe de volgende symbolen in:

$\mathrm{T}$ de totale (jaar)capaciteit van het duurzame productiemiddel, in werkeenheden. (Daar er in het voorbeeld maar van één duurzaam productiemiddel sprake is, geeft dit tevens de jaarcapaciteit van het bedrijf aan).

$\mathbf{x} \quad$ het aantal eenheden $\mathrm{P}$

y het aantal eenheden $Q$

$a_{p} \quad$ het aantal werkeenheden van het duurzame productiemiddel, dat benodigd is voor de productie van 1 eenheid $P$

$a_{q} \quad$ idem voor de productie van 1 eenheid $Q$

$b_{p} \quad$ het antal eenheden van de variabele factor, dat benodigd is voor de productie van 1 eenheid $\mathrm{P} 4$ )

$b_{q} \quad$ idem voor de productie van 1 eenheid $Q$

$\mathrm{c}_{\mathbf{a}}$ de prijs van 1 werkeenheid van het duurzame productiemiddel

$c_{b} \quad$ de prijs van 1 eenheid van het variabele productiemiddel

$V_{p}$ de verkoopprijs van 1 eenheid $P$

$V_{q}$ de verkoopprijs van 1 eenheid $Q$

$W^{N} \quad$ de totale netto-jaarwinst

$W^{\text {B }}$ de totale bruto-jaarwinst

$\mathrm{W}\left(\mathrm{o}, \mathrm{y}^{\star}\right)$ de totale jaarwinst, als $\mathrm{x}=\mathrm{o}$ en $\mathrm{y}$ de maximale waarde aanneemt, zodat $\mathrm{y}=\mathrm{y}^{\star}$

$W\left(x^{\star}, o\right)$ de totale jaarwinst, als $y=o$ en $x$ de maximale waarde aanneemt, zodat $\mathrm{x}=\mathrm{x}^{\star}$.

We kunnen nu de volgende formule opstellen voor de totale netto-winst: $\mathrm{W}^{\mathrm{N}}=\mathrm{V}_{\mathrm{p}} \mathrm{x}+\mathrm{V}_{\mathrm{q}} \mathrm{y}-\mathrm{x}\left(\mathrm{c}_{\mathrm{a}} \mathrm{a}_{\mathrm{p}}+\mathrm{c}_{\mathrm{b}} \mathrm{b}_{\mathrm{p}}\right)-\mathrm{y}\left(\mathrm{c}_{\mathrm{a}} \mathrm{a}_{\mathrm{q}}+\mathrm{c}_{\mathrm{b}} \mathrm{b}_{\mathrm{q}}\right) \ldots \ldots$ (1)

Wanneer het productie-apparaat volledig bezet is, geldt:

Uit (2) volgt, dat:

$$
a_{p} x+a_{q} y=T \ldots \ldots(2)
$$

$$
y=\frac{T-a_{0} x}{a_{y}}
$$

Substitueren we de in (3) gevonden waarde van y in (1), dan krijgen we:

$$
W^{N}=x\left(V_{p}-c_{b} b_{p}\right)+\frac{\left(T-a_{p} x\right)\left(V_{q}-c_{b} b_{q}\right)}{a_{4}}-c_{a} T \ldots .
$$

Wanneer wij de getallen uit het voorbeeld van Winselaar invullen, dan komt er:

$$
\mathrm{W}^{\mathrm{N}}=\mathrm{x}(9-1.2)+\frac{(100000-8 \mathrm{x})(11-1.8)}{2}-1.100000
$$

Dit is maximaal, nl. 50.000 , voor $x=o$ en dat is dezelfde uitkomst als Winselaar vond.

De totale bruto-winst kan als volgt weergegeven worden:

$$
\mathrm{W}^{\mathrm{B}}=\mathrm{x}\left(\mathrm{V}_{\mathrm{p}}-\mathrm{c}_{\mathrm{b}} \mathrm{b}_{\mathrm{p}}\right)+\mathrm{y}\left(\mathrm{V}_{\mathrm{q}}-\mathrm{c}_{\mathrm{b}} \mathrm{b}_{\mathrm{q}}\right)
$$

Indien wij weer $y$ in $x$ uitdrukken, zodat $y=\frac{T-a_{p} x}{a_{q}}$ en dit in (5) substitueren, geldt: $W^{B}=x\left(V_{p}-c_{1} b_{p}\right)+\frac{\left(T-a_{p} x\right)\left(V_{q}-c_{1} b_{q}\right)}{a_{q}}$

4) Daar voor het eerste en tweede door Winselaar behandelde geval ( $a$ en b) het onderscheid tussen directe lonen en directe materialen niet van belang is, vatten we deze beide samen tot één variabele factor. 
Vullen we wederom de getallen uit het voorbeeld in, dan is:

$$
\begin{aligned}
W & =x(9-1.2)+\frac{(100000-8 x)(11-1.8)}{2} \\
& =150000-5 x
\end{aligned}
$$

Deze uitkomst stemt overeen met die van Winselaar.

Het verloop van de totale bruto-winst, totale netto-winst en de kostenfactoren kan weergegeven worden in een $\mathrm{zg}$. break-even chart, die hieronder volgt.

1000 GLD.

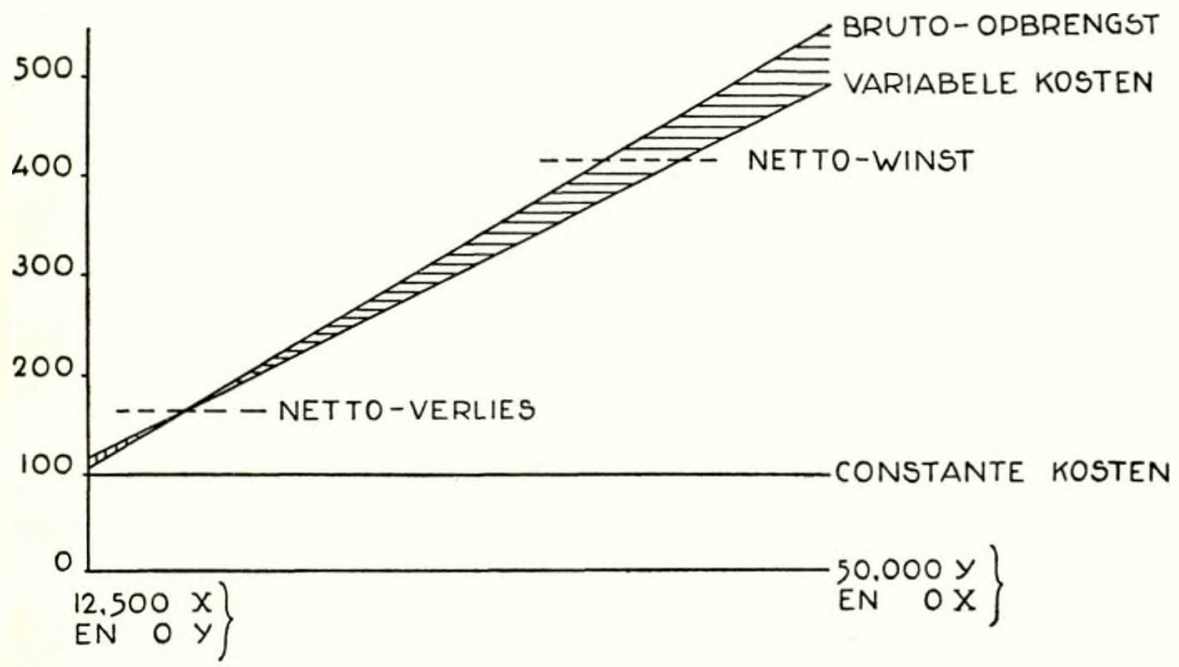

fig. 1

Het bleek hierboven, dat de winst slechts maximaal kan zijn als hetzij $\mathrm{x}=\mathrm{x}^{\star}$ en $\mathrm{y}=\mathrm{o}$, hetzij $\mathrm{x}=$ o en $\mathrm{y}=\mathrm{y}^{\star}$.

Laten we eens aannemen, dat de winst maximaal is voor $\mathrm{x}=$ o en $\mathrm{y}=\mathrm{y}^{*}$. D.w.z.: $\mathrm{W}\left(\mathrm{o}, \mathrm{y}^{\star}\right)>\mathrm{W}\left(\mathrm{x}^{*}, \mathrm{o}\right)$. Hiervoor kan in de plaats geschreven worden, - afgeleid uit (4) -:

$$
-c_{a} T+\frac{T\left(V_{q}-c_{b} b_{q}\right)}{a_{a}}>-c_{a} T+\frac{T\left(V_{p}-c_{b} b_{p}\right)}{a_{p}}
$$

Of: $\frac{V_{q}-c_{b} b_{q}}{a_{q}}>\frac{V_{p}-c_{b} b_{p}}{a_{p}}$. Hieruit volgt: $\frac{a_{p}}{a_{q}}<\frac{V_{p}-c_{b} b_{p}}{V_{q}-c_{b} b_{q}} \ldots$

Evenzo vinden we, als $W\left(o, y^{*}\right)<W\left(x^{*}, o\right)$, dat $\frac{a_{b}}{a_{q}} \leqslant \frac{V_{b}-c_{b} b_{p}}{V_{q}-c_{b} b_{q}}$

Welke combinatie van $\mathrm{x}$ en $\mathrm{y}$ gekozen moet worden hangt dus niet af van het feit, zoals Winselaar beweerde, of voor 1 eenheid $\mathrm{P}$ meer werkeenheden benodigd zijn dan voor 1 eenheid $Q$ (of van $a_{p}>a_{q}$ ), maar van de vraag, of $(6 a)$ of $(6 b)$ geldt.

In Winselaar's voorbeeld blijkt voldaan te zijn aan $(6 a)-n l$. $\frac{8}{2}>\frac{9-1.2}{11-1.8} \rightarrow 4>2 \frac{1}{3}-$ en om deze reden moet besloten worden tot de productie van o eenheden $\mathrm{P}$ en 50.000 eenheden $\mathrm{Q}$.

De formules (6a) en (6b) gelden uitsluitend onder de voorwaarde, dat 
$V_{p}-c_{b} b_{p}>0$ en $V_{q}-c_{b} b_{q}>0$ (verkoopprijzen groter dan variabele kosten). Het is wel te begrijpen hoe Winselaar tot de voorwaarde $a_{p}>a_{q}$ kwam, daarvoor is het nl. vereist, dat ook geldt: $V_{p}-c_{b} b_{p}>V_{q}-c_{b} b_{q}$. $\mathrm{Er}_{\mathrm{r}}$ is echter geen enkele noodzaak om van een dergelijke beperkende ver. onderstelling uit te gaan.

Om der wille van de duidelijkheid hebben we in de formules voor de nettoen de bruto-winst voor $y$ de term $\frac{T-a_{p} x}{a_{q}}$ gesubstitueerd.

$\mathrm{Nu}$ echter gebleken is, dat wij slechts te maken hebben met de uiterste waarde van $x$ en $y$, kunnen we op eenvoudiger wijze te werk gaan en de maximale netto-winst vinden door na te gaan of:

$$
\frac{T}{a_{p}}\left(V_{p}-c_{i l} a_{p}-c_{b} b_{p}\right) \leqslant \frac{T}{a_{q}}\left(V_{q}-c_{a} a_{q}-c_{b} b_{q}\right) .
$$

Voor de bruto-winst geldt m.m. hetzelfde.

Er kan nu ook nog op zeer eenvoudige wijze aangetoond worden, dat er geen reden is, waarom de bruto-winst per artikel tot een zelfde uitspraak zou moeten leiden als de totale bruto-winst.

Stel, dat $V_{p}-c_{b} b_{p}>0$ en $V_{a}-c_{b} b_{q}>0$ en dat ook $V_{p}-c_{b} b_{p}>V_{q}-c_{b} b_{q}$. $\mathrm{Nu}$ is het de vraag, of ook $x^{*}\left(V_{p}-c_{b} b_{p}\right)>y^{\star}\left(V_{q}-c_{b} b_{q}\right)$ geldt, d.w.z. of ook de bruto-winst bij productie van $\mathrm{x}=\mathrm{x}^{\star}$ en $\mathrm{y}=\mathrm{o}$ groter is dan de bruto-winst in het geval dat $\mathrm{x}=\mathrm{o}$ en $\mathrm{y}=\mathrm{y}^{*}$.

$x^{\star}$ kan zowel groter als kleiner dan $y^{\star} z i j n^{5}$ ) en dientengevolge kan men geen enkele uitspraak doen omtrent de grootte-verhouding van de brutowinst in totaal (m.a.w. over het teken van de nieuwe ongelijkheid).

Voorts is nog de vraag gerechtigd, of het noodzakelijk is, dat totale bruto-winst en totale netto-winst altijd tot een zelfde aanwijzing voor het productie-programma leiden, of dat dit slechts zo uitkomt door Winselaar's cijferkeuze.

Het verschil tussen bruto-winst en netto-winst is gelegen in de offers voor het duurzame productie-apparaat. Deze zijn gelijk, welke van de twee mogelijke combinaties van $\mathrm{x}$ en $\mathrm{y}$ men ook kiest.6)

Is de totale bruto-winst bij productie van uitsluitend $\mathrm{P}$ groter dan de totale bruto-winst bij productie van uitsluitend $\mathrm{Q}$ (beide uiteraard in de maximale hoeveelheid), dan is de totale netto-winst in het geval dat de maximaal mogelijke hoeveelheid $\mathrm{P}$ geproduceerd wordt evenveel kleiner dan de totale bruto-winst, als in het geval dat de maximaal mogelijke hoeveelheid $Q$ geproduceerd wordt.

Inderdaad leiden totale netto-winst en totale bruto-winst dus altijd tot eenzelfde richtlijn voor de productie.

\section{Beperkte afzet en onderbezetting.}

In geval b) neemt $W$ inselaar aan, dat de afzet - en hiermede tevens de productie - niet meer bedraagt dan 10.000 artikelen, terwijl stilzwijgend aangenomen wordt, dat er geen voorraadvorming plaats vindt.

Het geval a), waarin de volledige productie tegen de gegeven prijzen kon worden afgezet, duidde Winselaar aan met de voorwaarde , $\mathrm{n} \leqq 12.500^{\prime}$.

Geval b) - de afzet is beperkt - omschreef Winselaar met ,n $\leqq 10.000^{\prime \prime}$. Zonder ons nog in een nadere uitwerking te begeven, kunnen wij zo wel inzien, dat dit geval niet erg zinvol is.

5) De mogelijkheid, dat $x^{*}=y^{*}=$ o sluiten we uit, want dit leidt tot een trivale oplossing.

6) Daar het productie-apparaat volledig bezet is, kunnen de offers ervoor als kosten beschouwd worden (overige verspilling uitgesloten). 
Stel bij voorbeeld, dat het betrokken bedrijf een schoenfabriek is, die zowel dames- als herenschoenen vervaardigt (beide soorten schoenen in één uitvoering). Dan zou het de afnemers onverschillig moeten zijn, of zij 10.000 (of 5.000, al naar gelang men één schoen of een paar schoenen als eenheid aanneemt) herenschoenen of 10.000 damesschoenen zouden ontvangen; de enige beperkende voorwaarde is immers, dat de totale afzet niet groter is dan 10.000 artikelen.

Laten wij er ons op dit punt eerst rekenschap van geven, wat wij onder „beperkte afzet" en „onderbezetting" wensen te verstaan.

In de strikte zin des woords is voor iedere individuele producent de afzet van een bepaald artikel in de praktijk altijd beperkt, daar het hem nooit mogelijk is er een oneindig grote hoeveelheid van af te zetten. Met een dergelijke opvatting van het begrip ,beperkte afzet" komen we echter niet veel verder. We zullen daarom de afzet van een product $P$ voor een individueel bedrijf beperkt noemen, als de hoeveelheid, die tegen de gegeven prijzen kan worden afgezet kleiner is dan de hoeveelheid die men, bij volledige bezetting van het productie-apparaat met de productie van $\mathrm{P}$, kan produceren.

Als we $O_{p}$ de potentiële afzet van $P$ en $O_{q}$ de potentiële afzet van $Q$ noemen, dan is de afzet van $P$ beperkt als $\mathrm{O}_{\mathrm{p}}<\mathrm{x}^{*}$ en de afzet van $\mathrm{Q}$ beperkt als $\mathrm{O}_{\mathrm{q}}<\mathrm{y}^{\star}$.

Schrijven we $\operatorname{nog} \frac{O_{p}}{x^{\star}}=\alpha$ en $\frac{O_{q}}{y^{*}}=\beta$, dan is de afzet van P beperkt als $\alpha<1$ en de afzet van $Q$ beperkt als $\beta<1 .(\alpha \geqq 0, \beta \geqq 0)$.

Het behoeft weinig betoog, dat een bedrijf onderbezet is, zodra niet de hele productie-capaciteit aangewend wordt. Het is echter niet zo, dat beperkte afzet tevens inhoudt, dat het bedrijf onderbezet is.

Wanneer wij ons tot twee artikelen beperken, dan kan de totale potentiële afzet $-O_{p}+O_{q}-$ ook als geldt: $O_{p}<x^{\star}$ en $O_{q}<y^{\star}$, heel wel groter zijn dan de hoeveelheid, die bij volledige bezetting geproduceerd kan worden.

Het bedrijf is in dit geval slechts onderbezet, als men door $O_{p}$ én $O_{q}$ te produceren het productie-apparaat niet volledig kan bezetten.

Zouden we ervan uit gaan, dat het bedrijf slechts één artikel produceert, dan betekent beperkte afzet wel tegelijkertijd onderbezetting. Zodra het bedrijf meer dan één artikel voert, geldt dit dus niet meer.

Terugkerend tot de voorbeelden van Winselaar blijkt, dat in geval a) gold: $o \leq x \leq 12.500$ en $o \leqq y \leqq 50.000$. Wanneer men uitsluitend let op de productie-voorwaarden, kunnen $\mathrm{x}$ en $\mathrm{y}$ alle waarden tussen o en 12.500 resp. 50.000 aannemen, met dien verstande dat $x=0$ inhoudt, dat $y=50.000$ en $x=12.500$ leidt tot $y=0$. Zodra men de afzet erbij betrekt, zullen in feite $\mathrm{x}$ en $\mathrm{y}$ slechts in hun uiterste waarden voorkomen, daar $\mathrm{O}_{\mathrm{p}} \geqslant \mathrm{x}$ en $\mathrm{O}_{q} \geqslant \mathrm{y}$. In geval b) geldt evenzeer, dat $\mathrm{o} \leqq \mathrm{x} \leqq 12.500$ en $\mathrm{o} \leqq \mathrm{y} \leqq$ 50.000. Zodra men de afzet erbij in aanmerking neemt $-\mathrm{O}_{\mathrm{p}}+\mathrm{O}_{\mathrm{q}}=10.000$ - ziet men, dat de feitelijke waarden van $\mathrm{x}$ en y tussen o en 10.000 komen te liggen.

In a) was de voorwaarde ,n $\mathrm{n} \leqq 12.500^{\prime \prime}$ afgeleid uit , $\mathrm{n}^{\prime \prime}=\frac{\mathrm{T}}{\mathrm{a}_{\mathrm{p}}}$, d.i. , $\mathrm{n} "=\frac{100.000}{8}$ terwijl voor artikel $Q$ geldt, dat $y(=, 12.500-\mathrm{n} ")=\frac{T}{\mathrm{a}_{\mathrm{q}}}$.

In $\mathrm{b}$ ) is , $\mathrm{n} \leqq 10.000$ " niet uit de structuur van het bedrijf afgeleid, maar ,$n$ " wordt aan een nieuwe beperking onderworpen, nl. , $n " \leqq O_{p}+O_{q}$. 
waarbij, nogmaals, $\mathrm{O}_{p}$ en $\mathrm{O}_{q}$ niet uit de technische productie-voorwaarden $\left(T, a_{p}, a_{q}\right)$ zijn af te leiden.

Laten wij nu de conclusie, die Winselaar uit geval b) trekt, wat nader bezien. Hij schrijft: „Hoewel de calculatie aangeeft, dat op ieder artikel P $f$ 1, - wordt verloren en op ieder artikel $Q f$ 1, - wordt verdiend, blijkt uit vorenstaande berekening dus, dat bij de productie van 10.000 artikelen $\mathrm{P}$ het resultaat gunstiger (of minder ongunstig) is dan bij de productie van 10.000 artikelen $Q$. Bij nadere beschouwing blijkt dit te worden veroorzaakt door het feit, dat terwijl ieder artikel $\mathrm{P}$ beslag legt op 8 capaciteitseenheden, er voor ieder artikel $Q$ slechts 2 senheden benodigd zijn. Hieruit volgt, dat bij productie van artikelen $\mathrm{P}$ de kosten van viermaal zoveel capaciteitseenheden worden gedekt als bij productie van een gelijk aantal artikelen $Q$. Het minder ongunstige resultaat .... wordt veroorzaakt door de betere bedrijfsbezetting ....".

Tenslotte trekt Winselaar de conclusie, zoals eerder vermeld, dat nu de bruto-winst per artikel wél tot een juiste uitspraak omtrent het productieprogramma leidt.

Uit het geciteerde blijkt dus, dat het productie-programma $10.000 \mathrm{P}$ en o eenheden $Q$ zou moeten zijn, omdat voor één artikel $P$ meer werk-eenheden van het duurzame productie-apparaat nodig zijn dan voor één artikel $\mathrm{Q}$, of omdat $\mathrm{a}_{\mathrm{p}}>\mathrm{a}_{\mathrm{q}}$.

Het is echter niet $z o$, dat $a_{p}$ iedere willekeurige eindige waarde zou kunnen hebben die groter is dan $\mathbf{a}_{\mathrm{q}}$.

Stel bij voorbeeld, dat $a_{p}=15$ en $a_{q}=2$. Dan is $\frac{T}{a_{p}}=x^{*}=6667$.

Wanneer nu de afzet beperkt is (de onrealistische voorwaarde , $\mathrm{n}=$ 10.000 " vervangen we door een andere, b.v. $\mathrm{O}_{p}=7.000$ en $\mathrm{O}_{q}=3.000$ ) dan zou tevens moeten gelden, dat $\mathrm{O}_{p}<\mathrm{x}^{*}$, hetgeen blijkbaar niet het geval is. ${ }^{7}$ )

Evenals het in het geval van niet beperkte afzet en volledige bezetting mogelijk was om een nadere uitspraak te doen omtrent de waarden van $a_{p}$ en $a_{q}$ (zie de formules $6 a$ en $6 b$ ). kunnen we ook hier een voorwaarde vinden, waar $a_{p}$ en $a_{\mathfrak{a}}$ aan moeten voldoen.

We stellen de totale bruto-winst daartoe weer voor als volgt:

$$
W^{\mathrm{B}}=\mathrm{x}\left(\mathrm{V}_{\mathrm{p}}-\mathrm{c}_{\mathrm{b}} \mathrm{b}_{\mathrm{p}}\right)+\mathrm{y}\left(\mathrm{V}_{\mathrm{q}}-\mathrm{c}_{\mathrm{b}} \mathrm{b}_{\mathrm{q}}\right)
$$

Stel nu, dat de winst bij productie van $\mathrm{O}_{\mathrm{p}}$ en o $\mathrm{Q}$ groter is dan de winst bij productie van o $\mathrm{P}$ en $\mathrm{O}_{\mathrm{q}}$, dan geldt:

$$
\mathrm{O}_{\mathrm{p}}\left(\mathrm{V}_{\mathrm{p}}-\mathrm{c}_{\mathrm{b}} \mathrm{b}_{\mathrm{p}}\right)>\mathrm{O}_{\mathrm{q}}\left(\mathrm{V}_{\mathrm{q}}-\mathrm{c}_{\mathrm{b}} \mathrm{b}_{\mathrm{q}}\right) \text {. }
$$

Eerder stelden we, dat $O_{p}=\alpha x^{\star}$ en $O_{q}=\beta y^{\star}$. Nu is $x^{\star}=\frac{T}{a_{p}}$ en $y^{\star}=\frac{T}{a_{q}}$. dus kunnen we schrijven:

$$
\alpha \frac{T}{a_{p}}\left(V_{p}-c_{b} b_{p}\right)>\beta \frac{T}{a_{q}}\left(V_{q}-c_{b} b_{q}\right)
$$

Hieruit volgt, dat: $\frac{a_{p}}{a_{q}}<\frac{\alpha\left(V_{p}-c_{p} b_{p}\right)}{\rho\left(V_{q}-c_{b} b_{q}\right)} \ldots$.

M.a.w., het antwoord op de vraag of de bruto-winst groter is bij de productie van $\mathrm{O}_{p}$ en o eenheden $\mathrm{Q}$ dan bij productie van o eenheden $\mathrm{P}$ en $\mathrm{O}_{\mathrm{q}}$ eenheden $Q$ hangt niet zonder meer af van de mate waarin voor 1 eenheid

7) Uit den aard der zaak geldt hetzelfde, als men - zoals Winselaar $-O_{p}$ de waarde 10.000 geeft. Is $a_{p}$ dan b.v. 12 , dan zou $10.000<\frac{100.000}{12}$ moeten zijn, quod non. 
P en 1 eenheid $Q$ beslag wordt gelegd op het productie-apparaat, maar dit wordt mede bepaald door de onderlinge verhouding van verkoopprijzen en variabele kosten.

$\mathrm{Nu}$ is echter - als voldaan is aan (7) - de bruto-winst bij productie van $\mathrm{O}_{\mathrm{p}}$ groter dan bij productie van $\mathrm{O}_{\mathrm{q}}$ (als in $(7)$ het >-teken staat is de winst bij productie van $\mathrm{O}_{q}$ groter dan bij productie $\mathrm{O}_{\mathrm{p}}$ ), maar bij deze productie wordt niet de maximaal mogelijke winst behaald.

In geval a) was het zo, dat als besloten werd tot productie van 50.000 eenheden $Q$, de productie van $P$ noodzakelijkerwijze nul moest zijn, omdat hiervoor geen productie-capaciteit meer beschikbaar was.

In het geval van onderbezetting zijn alle combinaties van $\mathrm{x}$ en $\mathrm{y}$ mogelijk, zolang maar - vanwege de geldende afzetbeperkingen - $\mathrm{x}$ niet groter is dan 7.000 en y niet groter dan 3.000 .

Het is dus heel goed denkbaar, dat productie van 5.000 eenheden $P$ en 1.000 eenheden $Q$ een grotere winst geeft dan productie van uitsluitend 7.000 eenheden $P$ en productie van 7.000 eenheden $P$ en 3.000 eenheden $Q$ nog weer een grotere winst.

Zodra de verkoopprijs de variabele kosten overtreft, is het lonend van het desbetreffende product die hoeveelheid te maken, die men maximaal kan afzetten. Alles wat men boven de variabele kosten ontvangt is een vergoeding voor de offers voor het duurzame productie-apparaat. Het zij met nadruk gezegd, dat deze constatering alleen geldt in geval van onderbezetting en bovendien alleen, als de productie onder ,opschortende voorwaarde" plaats vindt. Het heeft geen zin om door te gaan met produceren als er geen redelijke kans is, dat de verkoopprijs boven de totale kosten uitkomt.

Deze redenering geldt voor alle producten, die het bedrijf produceert. Als dus in het onderhavige geval de verkoopprijzen van $P$ en $Q$ groter zijn dan de variabele kosten, is de meest winstgevende combinatie die, waarbij zowel van $\mathrm{P}$ als van $\mathrm{Q}$ de hoeveelheid geproduceerd wordt, die men maximaal kan afzetten.

T'er verduidelijking kunnen we een en ander ook grafisch voorstellen (zie fig. II).

Uit de figuur lezen we af, dat indien $0 \leq x \leq 12.500$ en $0 \leq y \leq 50.000$, $\mathrm{y}=\frac{\mathrm{T}}{\mathrm{a}_{\mathrm{q}}}, \mathrm{O}_{\mathrm{p}} \geqslant \mathrm{x}, \mathrm{O}_{\mathrm{q}} \geqslant \mathrm{y}$, de grootste bruto-winst gemaakt wordt bij $y=50.000$ en $x=0$. Bij iedere lagere waarde van y en daarmee corresponderende waarde van $\mathrm{x}$ ligt de bruto-winst-lijn dichter bij de oorsprong ( "lager"), hetgeen wijst op een lager winstbedrag terwijl een bruto-winstlijn, die verder van de oorsprong af (,,hoger") ligt een grotere productie zon vereisen dan $y=50.000$, hetgeen onmogelijk is.

Evenzo valt af te lezen, dat weliswaar bij $x=7.000$ en $y=0$ een hogere winst behaald wordt dan bij $\mathrm{x}=0$ en $\mathrm{y}=3.000$, maar dat - in geval $\mathrm{O}_{\mathrm{p}}=7.000$ en $\mathrm{O}_{\mathrm{q}}=3.000$ - de maximale winst ligt bij $\mathrm{x}=7.000$ en $\mathrm{y}=$ 3.000 .

Ook in dit geval van onderbezetting geldt weer, dat totale bruto-winst en totale netto-winst tot eenzelfde productie-programma leiden. Immers, even als bij volledige bezetting geldt ook hier, dat, welke van de mogelijke combinaties van hoeveelheden $\mathrm{P}$ en $\mathrm{Q}$ men ook kiest, de offers voor het duurzame productie-apparaat gelijk zijn. Het is hier wederom zo, dat ook de totale offers voor het duurzame productie-apparaat - die voor het niet bezette 


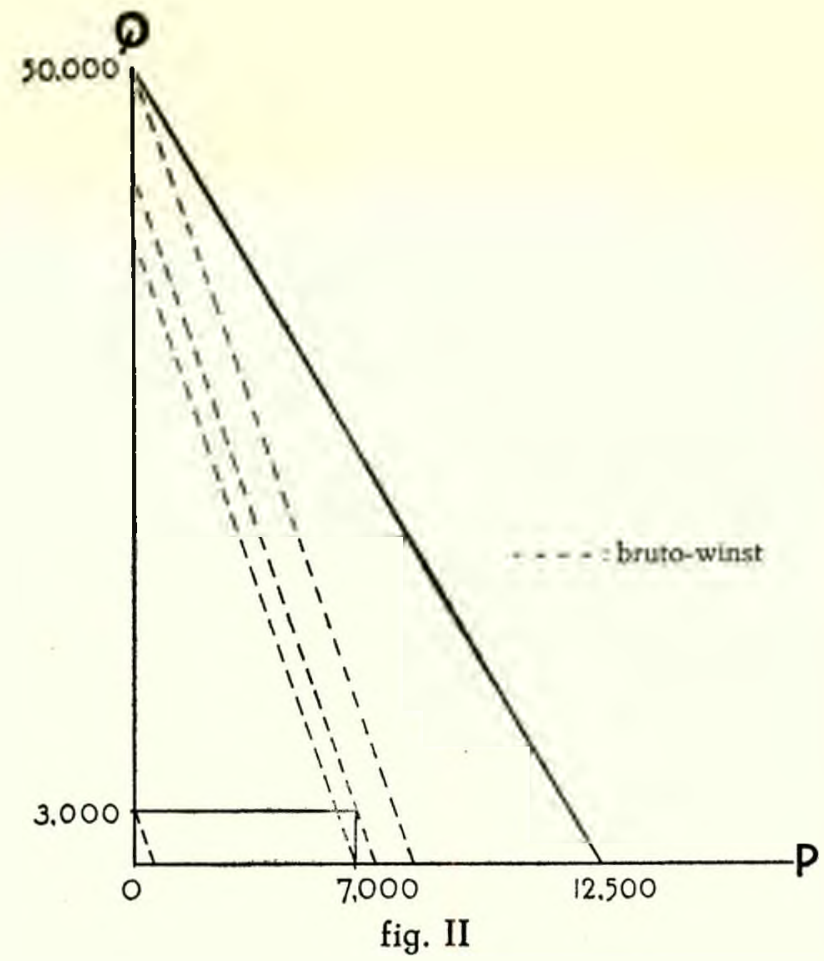

deel inbegrepen - in mindering van de totale opbrengst komen, alvorens men van netto-winst kan spreken. De bruto-winst per artikel blijkt een ondeugdelijke maatstaf te $z \mathrm{ijn}$, omdat $z \mathrm{ij}$ in het geheel niet tot een uitspraak leidt.

\section{Beschikbare aantal arbeiders beperkt.}

In de gevallen c) en d) behandelt Winselaar nog de situatie waarin er niet meer dan een bepaald bedrag aan directe lonen kan worden uitbetaald.

Ook voor deze gevallen gelden de algemene conclusies, waartoe wij hierboven kwamen.

De cijferopstelling van Winselaar is hier dusdanig, dat ternauwernood $z i j n$ bedoelingen na te gaan zijn. B.v. is het beslist onduidelijk, waarom ,,n", de hoeveelheid van product $\mathrm{P}$, niet o kan zijn.

Wellicht vindt Winselaar gelegenheid om zijn gedachten hierover nog eens in een herziene versie weer te geven.

\section{$V$. Conclusie.}

In het bovenstaande is gebleken, dat de bruto-winst per artikel nooit richtsnoer voor de productie-programmering kan zijn.

Het productie-programma behoort opgesteld te worden door na te gaan. welke combinatie van de hoeveelheden der producten tot maximale totale winst leidt.

Hierbij maakt het geen verschil, of men de berekening uitvoert aan de hand van de totale bruto- of de totale netto-winst. ${ }^{8}$ )

8) Voor andere doeleinden dan productie-programmering, met name de bepaling van het resultaat in de voortbrenging, is het niet onverschillig, of men de totale bruto-winst of de totale netto-winst beschouwt. 
Gesteld, de afzet is niet beperkt en er zijn ook overigens geen factoren, die volledige bezetting van het bedrijf verhinderen.

Als men in deze situatie het productie-apparaat volledig zou bezetten met de productie van één artikel en de winst zou dan groter zijn, dan indien het productie-apparaat volledig bezet ware met de productie van enig ander artikel, dat het bedrijf - technisch gesproken - zou kunnen produceren, dan moet het productie-programma zijn: de maximaal mogelijke hoeveelheid van het artikal met de grootste winst - en dus niets van de andere artikelen. Van welk artikel dit de maximale hoeveelheid zal zijn, hangt af van de onderlinge relatie van verkoopprijzen, kosten van het duurzame productieapparaat en overige kosten.

Is de afzet van een of meer producten beperkt, dan behoeft dit niet te betekenen dat het bedrijf onderbezet is.

Is de afzet beperkt én het bedrijf onderbezet, dan moet van alle producten, waarvan de verkoopprijzen de variabele kosten overtreffen, die hoeveelheid geproduceerd worden, die men maximaal kan afzetten en van de overige producten niets.

Dit alles geldt slechts, wanneer de betrekkingen tussen de verschillende grootheden van lineaire aard zijn.9)

9) Wanneer de relaties niet meer lineair zijn, kunnen andere combinaties van hoeveelheden product in aanmerking komen dan die, waarbij uitsluitend o of de maximaal mogelijke hoeveelheid (afzet- en overige beperkingen in aanmerking genomen) geproduceerd wordt. 